\title{
Phytochemical screening and anticancer activity of leaf extracts of Physalis minima
}

\author{
H.N. Krishna Kumar* and Jyoti Bala Chauhan \\ Department of Studies in Biotechnology, Microbiology \& Biochemistry \\ Pooja Bhagavat Memorial Mahajana Education Centre, PG wing of SBRR Mahajana First Grade College, \\ K.R.S. Road, Metagalli, Mysore-570 016, Karnataka, India
}

${ }^{*}$ Author for correspondance

\begin{abstract}
Physalis minima a medicinally important plant of the family Solanaceae has been screened for its anticancer activity. The results of preliminary phytochemical screening of the leaf extract revealed the presence of flavonoids, alkaloids, tannins, saponins, steroids, cardiac glycosides, reducing sugars and terpenoids. Determination of total phenolic contents revealed that methanolic extract showed $78.3 \mathrm{mg} / \mathrm{g}$ of phenolic compounds. Evaluation of total flavonoid content showed $61.3 \mathrm{mg} / \mathrm{g}$ of flavonoid. It was found that the \% viability of HeLa cell line \& $\mathrm{Hep}^{2}$ cell line are $80 \%$ \& $71.8 \%$ respectively. The percentage of growth inhibition of methanolic extract in SRB assay was found to be increase with increasing concentration against both HeLa and $\mathrm{Hep}^{2}$ cell lines (68 and 58\% respectively). The methanolic extract showed the strongest growth inhibitory effect on both HeLa and $\mathrm{Hep}^{2}$ cell lines (85 and 73\% respectively) in MTT assay. Flavonoids have been isolated and purified from the methanolic leaf extract.
\end{abstract}

Key words: Physalis minima, Anticancer activity, SRB assay, MTT assay, Phytochemicals

\section{INTRODUCTION}

Cancer is a leading cause among various diseases attributed to mortality in humans all over the world [1]. Plants have been a prime source of highly effective conventional drugs for the treatment of many forms of cancer. They have long history used in the treatment of cancer. Active constitutes of Catharanthus roseus, Angelica gigas, Podophyllum peltatum, Taxus brevifolia, Podophyllum emodii, Ocrosia elliptica, and Campototheca acuminata have been used in the treatment of advanced stages of various malignancies [2]. Many medicinal plants reported to have anti-cancer as well as antiinflammatory activity in the Ayurvedic system of medicine. Hartwell, in his review of plants used against cancer, lists more than 3000 plant species that have reportedly been used in the treatment of cancer [3]. It is significant that over $60 \%$ of currently used anti-cancer agents are derived in one way or another from natural sources, including plants, marine organisms and micro-organisms. Plant-derived compounds have played an important role in the development of several clinically useful anti-cancer agents. These include vinblastine, vincristine, the camptothecin derivatives, topotecan and irinotecan, etoposide, derived from epipodophyllotoxin, and paclitaxel.

Physalis minima belonging to the family of Solanaceae are an annual herb having 0.5-1.5 $\mathrm{m}$ height with a very delicate purple-tinged stem and leaves. It is found throughout India and is reported as one of the important medicinal plants in Indian traditional system of medicines. It is found on the bunds of the fields, wastelands, around the houses, on roadsides, etc. where the soil is porous and rich in organic matter. Leaves are petiolate, ovate to cordate. Flowers are pedicellate, hermaphrodite, complete, solitary and companulate. The flowering and fruiting season starts from March-April and continues up to the end of November. Fruits are a berry, enclosed within the enlarged, ribbed, reticulately veined calyx, which is $4.1 \mathrm{~cm}$ long and $2.5 \mathrm{~cm}$ broad [4-6]. It has been used traditionally in the treatment of various ailments and it contains steroidal lactones, steroids, alkaloids and flavanoids compounds in various parts. The plant is appetizing, diuretic, laxative and useful in inflammations, antigonorrhoeic, enlargement of the spleen and abdominal troubles [7]. Fruits and flowers are used in stomach pain and in constipation, Herb paste is applied in ear disorders [8]. Ripen fruits are used in gastric trouble [9]. The decoction of the whole plant is consumed by the Malay community in Malaysia as a remedy for cancer [10]. It is used in treatment of asthma, bronchitis, inflammation, enlargement of spleen, urinary disorder, abdominal troubles and headache. The roots are used as vermifuge and febrifuge and treatment of diabetes [11, 12]. Further, pharmacological and phytochemical exploration is required for systematic investigation of this plant. The aim of the present study was to evaluate anticancer activity of the leaf extracts.

\section{MATERIALS AND METHODS}

\section{Chemicals}

Methanol, Fehling's solution (A and B), Ammonia, Aluminium chloride, Ferric chloride, Acetic acid, Mayer's reagent, Draggendorff's reagent, Folin-Ciocalteu reagent, Sodium carbonate, Gallic acid, Sodium nitrite, Sodium hydroxide, were purchased from M/S Sisco Research laboratories, Mumbai, India. Quercetin, Trypan Blue, 
Sulphorodamine B, Trichloroacetic acid, MTT [3-(4, 5-Dimethylthiazol-2-yl)-2, 5-Diphenyltetrazolium Bromide], Dimethyl sulfoxide were purchased from Sigma (St. Louis, USA). All chemicals and solvents used were of analytical grade.

\section{Plant material collection and extraction}

The leaves of Physalis minima for the present investigation was collected from different areas in Karnataka such as Bangalore, Chikmagalur, Karwar, Mysore, Shimoga, Tumkur and Uttarakannada district. The collected materials were washed thoroughly in water, shade dried for a week and ground to a coarse powder in electric grinder. Hundred grams of powder was extracted in soxhlet apparatus successively with solvents of increasing polarity viz., hexane, ethyl acetate, acetone and methanol separately. The soxhelation process was carried out until the solvent was found to be colorless. The extracts were concentrated using a rotary flash evaporator. The aqueous extract was prepared by homogenizing the powder in distilled water for $24 \mathrm{hrs}$ in a shaker, the mixture was filtered and the filtrate was lyophilized.

\section{Phytochemical analysis}

The prepated extracts were studied for their phytoconstituents such as flavonoids, alkaloids, terpenoids, tannins, saponins, reducing sugars, steroids, anthraquinones and cadiac glycosides. Phytochemical screening was perfomed using standard procedures [13].

\section{Determination of Total phenolics}

The total phenolic content of the methanolic extract was evaluated by using the method described by Singleton and Rossi [14] with slight modifications. Briefly, $1 \mathrm{~mL}$ of sample was mixed with $1 \mathrm{ml}$ of Folin-Ciocalteu reagent. After $3 \mathrm{~min}, 1 \mathrm{~mL}$ of saturated $\mathrm{Na}_{2} \mathrm{CO}_{3}$ solution was added to the mixture followed by the addition of $7 \mathrm{ml}$ of distilled water. The mixture was kept in the dark for $90 \mathrm{~min}$, after which the absorbance was read at $725 \mathrm{~nm}$. The total phenol contents were determined using a standard curve prepared with gallic acid. The results were mean \pm standard deviations and expressed as milligram of gallic acid equivalent $/ g$ of extract.

\section{Determination of Total flavonoids}

The total flavonoid content of methanolic extract was determined by the method described by Zhishen et al [15]. Briefly, $250 \mu \mathrm{l}$ of sample was mixed with $1 \mathrm{ml}$ of distilled water and $150 \mu \mathrm{l}$ of sodium nitrite solution. After 6 minutes, $75 \mu \mathrm{l}$ of aluminium chloride solution was added and then the mixture was allowed to stand for a further $5 \mathrm{minutes}$. Then, $1 \mathrm{ml}$ of $\mathrm{NaOH}$ solution was added. The mixture was made up to $2.5 \mathrm{ml}$ with distilled water. The absorbance was measured at $510 \mathrm{~nm}$. Total flavonoid content was expressed as $\mathrm{mg}$ quercetin equivalent (QE)/g dried extract. The values expressed are the average of three measurements.

\section{Anticancer activity}

\section{Cell lines}

HeLa and $\mathrm{Hep}^{2}$ Cell lines were collected from National Centre for Cell Science, University of Pune Campus, Pune for anticancer activity study. The percentage viability of the cell line was carried out by using Trypan blue dye exclusion method. Antitumor potentials of prepared extracts against $\mathrm{HeLa}$ and $\mathrm{Hep}^{2}$ cell lines were investigated using SRB and MTT assay.

\section{Trypan blue dye exclusion assay}

The percentage of viability of cell lines was determined by using trypan blue dye exclusion technique [16, 17]. Briefly, $50 \mu \mathrm{L}$ of cell suspension was mixed with an equal volume of trypan blue. The mixture was transferred to a hemocytometer and counted the live cell as clear form and dead cell as blue from under inverted microscope. The percent viability has been calculated by using the following equation:

$$
\% \text { viability }=(\text { live cell count/total cell count) } \mathrm{X} 100
$$

\section{Sulphorodamine B assay}

Antitumor potentials of the extracts were determined according to the method described by Skehan et al and Masters [18, 19]. Briefly, the monolayer cell culture was trypsinized and the cell count was adjusted to $0.5-1.0 \times 105$ cells $/ \mathrm{ml}$. To each well of the 96 well microtitre plate, $0.1 \mathrm{ml}$ of the diluted cell suspension (approximately 10,000 cells) was added. After 24 hours, the supernatant was flicked off, washed once and $100 \mu \mathrm{l}$ of different extracts with different concentrations were added to the cells in microtitre plates. The plates were then incubated at $37^{\circ} \mathrm{C}$ for 72 hours in $5 \% \mathrm{CO} 2$ incubator. After 72 hours, $25 \mu \mathrm{l}$ of $50 \%$ trichloroacetic acid was added to the wells gently and were incubated at $4^{\circ} \mathrm{C}$ for one hour. The plates

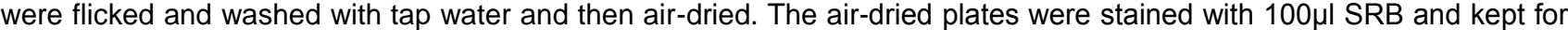
30 minutes at room temperature. The unbound dye was removed by rapidly washing with $1 \%$ acetic acid. $100 \mu \mathrm{l}$ of $10 \mathrm{mM}$ Tris base was then added to the wells and the absorbance was measured at $540 \mathrm{~nm}$. The percentage growth inhibition was calculated using following formula:

$$
\% \text { cell inhibition }=100-[(A t-A b) /(A c-A b)] \times 100
$$

Where, $A t=$ Absorbance value of test compound, $A b=$ Absorbance value of blank and $A c=A b s o r b a n c e$ value of control 


\section{MTT assay}

Cytotoxicity of the extracts was assessed by standard protocol $[20,21]$. In brief, the cells were seeded into 4 wells of a 96-well micro titer plate at $2 \times 10^{4}$ cells per well with $100 \mu \mathrm{l}$ growth medium and then incubated for 24 hrs. at $37^{\circ} \mathrm{C}$ under $5 \% \mathrm{CO}_{2}$. Then, the medium was removed and fresh growth medium containing prepared extracts at different concentrations $(40,80,120,160$ and $200 \mu \mathrm{g} / \mathrm{ml})$ were added separately and incubated at $37{ }^{\circ} \mathrm{C}$ for 3 days. The medium was removed after incubation and $0.1 \mathrm{mg} / \mathrm{ml}$ MTT reagent was added and incubated for $5 \mathrm{hrs}$. at $37^{\circ} \mathrm{C}$. Then, the MTT reagent was removed and $100 \mu \mathrm{l}$ of DMSO was added to each well. The absorbance was read at $516 \mathrm{~nm}$. The inhibition of cell growth was calculated using the following formula:

$$
[(\mathrm{Ac}-\mathrm{As}) / \mathrm{Ac}] \times 100
$$

Where $A c$ is the absorbance of the control and As is the absorbance of the sample. The results were mean \pm standard deviations.

\section{Isolation and partial purification of anticancer compounds}

The compounds were isolated and purified from the methanolic extract by using different chromatographic techniques (TLC, Column chromatography and HPLC). The compounds were characterized using standard techniques (UV-visible, LC-MS).

\section{Thin layer chromatography (TLC)}

Phytoconstituents of the methonolic leaf extract of Physalis minima were separated using thin layer chromatography (TLC). Aliquots of $200 \mu \mathrm{g}$ of extracts were loaded on TLC plates (TLC F254; Merck, India). Different solvent systems of varying polarity were used to separate anticancer compounds. The solvent system acetone and ethyl acetate $(60: 40 \mathrm{v} / \mathrm{v})$ showed the best separation. The developed plates were air dried and exposed to iodine to locate the spots.

\section{Colum chromatography}

The column was packed in the form of slurry of silica gel (60-120 mesh,) and gradient elution was carried out by using different combinations of solvents. The respective fractions were collected and concentrated by flash evaporation. Similar fractions were pooled after TLC analysis then assayed for anticancer activity.

\section{HPLC}

The isolated bioactive compounds were tested for its purity using HPLC [LC-solution, ShimadzuTM, MAO 1527, USA with LC-UV-100 UV detector, A CAPCELL(C-18) Column RP $(18.5 \mu \mathrm{m}, 250 \times 4.0 \mathrm{~mm})$, type MG 520 $\mu \mathrm{m}$, number AKAD/05245]. The mobile phase consisted of solvent mixtures (Acetonitrile: Water- 70:30) with a flow rate of $1.0 \mathrm{ml} / \mathrm{min}$. The injection volume was $20 \mu \mathrm{l}$, and UV detection was effected at $254 \mathrm{~nm}$.

\section{Identification of bioactive compounds by analytical methods}

\section{UV-visible spectrometry}

The UV-visible spectrum of the isolated compound in HPLC grade methanol was recorded by using Shimadzu 160A UV- visible spectrophotometer.

\section{Liquid Chromatography-Mass Spectrometry (LC-MS)}

The system consisted of a Hitachi L-6000 pump (Hitachi, Tokyo, Japan), a Rheodyne model 7125 injector with a $25 \mathrm{~mL}$ loop, and a 4.6 i.d. $325.0 \mathrm{~mm}$ Devosil C30 UG-5 column (Nomura Chemical, Seto, Japan). LC was performed using an aqueous solution containing methanol and acetonitril as the mobile phase at a flow rate of $1 \mathrm{~mL} / \mathrm{min}$. The spectra were recorded on a TSQ 700 triple-quadrupole mass spectrometer (Finnigan MAT, San Jose, CA) equipped with an ESI source with an ICIS II data system in the positive ion mode using a spray voltage of $9.8 \mathrm{kV}$, at a source temperature of $90^{\circ} \mathrm{C}$. The flow rate was $10 \mu \mathrm{L} / \mathrm{min}$.

\section{Statistical analysis}

All experiments were carried out in triplicates. Data were expressed as mean \pm standard error.

\section{RESULTS AND DISCUSSION}

\section{Phytochemical analysis}

The results of preliminary phytochemical screening of the leaf extract of Physalis minima from different solvent system revealed the presence of flavonoids, alkaloids, tannins, saponins, steroids, cardiac glycosides, reducing sugars and terpenoids (Table 1). Members of the Solanaceae like Solanum nigrum, Physalis peruviana, Capsicum fruitescence etc. have proven anti-cancer as well as anti-inflammatory activity. They possess medicinal properties like antimicrobial, antioxidant, cytotoxic properties, antiulcerogenic, and hepatoprotective activity. Solanum nigrum is a potential herbal alternative as anti-cancer agent and one of the active principles reported to be responsible for this action is Diosgenin [22, 


\section{ISSN $2393-9257$ \\ Volume $3 \mathrm{Number} 2$ \\ Journal of Advances in Natural Sciences}

23]. Plants are storehouse of pre-synthesized molecules that act as lead structures, which can be optimized for new drug development. In practice, a large number of cancer chemotherapeutic agents that are currently available in the market can be traced back to their plant source [24].

\section{Determination of Total phenolics and flavonoids}

Evaluation of total phenolic contents revealed that methanolic leaf extract showed $78.3 \mathrm{mg} / \mathrm{g}$ of phenolic compounds. The phenolic concentration of the extract was expressed as milligram of gallic acid equivalents per gram of extract. Likewise, methanolic leaf extract showed $61.3 \mathrm{mg} / \mathrm{g}$ of flavonoid. The flavonoid content was expressed as mg quercetin equivalent per gram of extract. The results of the present work strongly suggest that phenolic compounds are important components of this plant and some of their pharmacological effects could be attributed to the presence of these valuable constituents. Thus, the anticancer activity of the extract could be predicted from its total phenolic content. The interests in phenolic compounds, particularly flavonoids and tannins have considerably increased in recent years because of their broad spectrum of chemical and diverse biological properties which include the antioxidant effects [25]. It is suggested that polyphenolic compounds have inhibitory effects on mutagenesis and carcinogenesis in humans, when up to $1.0 \mathrm{~g}$ daily ingested from a diet rich in fruits and vegetables [26].

\section{Anticancer activity}

\section{Viability and characterization of cell lines}

Percentage cell viability of cell lines was carried out by using Trypan blue dye exclusion technique. It was found that the $\%$ viability of HeLa cell line \& $\mathrm{Hep}^{2}$ cell line are $80 \%$ \& $71.8 \%$ respectively, which are most suitable to perform cytoxicity studies.

\section{Sulphorhodamine B (SRB) assay}

Results are tabulated in Table 2. The percentage growth inhibition was found to be increasing with increasing concentration of test compounds against both the cell lines ( $\mathrm{HeLa}$ and $\mathrm{Hep}^{2}$ ). The methanolic extract showed the strongest growth inhibitory effect on both $\mathrm{HeLa}$ and $\mathrm{Hep}^{2}$ cell lines (68 and 58\% respectively) whereas in comparison ethyl acetate and acetone extract demonstrated moderate cytotoxic effect with \% inhibition of 51 \& 47 for HeLa and 58 \& 50 for $\mathrm{Hep}^{2}$ cell lines respectively (Table 2). In contrast hexane and aqueous extract did not show cytotoxic effect at any concentration. The result indicates that the methanolic leaf extract of Physalis minima has potential activity on both HeLa and $\mathrm{Hep}^{2}$ cell lines. The chloroform extract of $P$. minima is reported to possess cytotoxic activities on $\mathrm{NCl}-\mathrm{H} 23$ (human lung adenocarcinoma) cell line at dose- and timedependent manners. They exert programmed cell death in $\mathrm{NCl}-\mathrm{H} 23$ cells with typical DNA ftagmentation, which is a biochemical Hallmark of apoptosis [27].

\section{MTT assay}

In the present investigation, the leaf extract of Physalis minima showed significant effects on the tumor inhibition activities against cell lines of HeLa and $\mathrm{Hep}^{2}$ in MTT assay. It was found that the percent growth inhibition increasing with increasing concentration on both the cell lines. The methanolic extract showed the strongest growth inhibitory effect on both HeLa and $\mathrm{Hep}^{2}$ cell lines( 85 and $73 \%$ ) whereas, in comparison ethyl acetate and acetone extract demonstrated moderate cytotoxic effect with \% inhibition of 58 \& 65 for $\mathrm{HeLa}$ and $51 \& 61$ for $\mathrm{Hep}^{2}$ cell lines respectively (Table 3 ). In contrast hexane and aqueous extract did not show cytotoxic effect at any concentration. The result indicates that the methanolic leaf extract of Physalis minima has potential activity on both HeLa and Hep ${ }^{2}$ cell lines. The chloroform extract showed anticancer activity against human T-47D breast carcinoma cells. The cytotoxic action of chloroform extract is reported to be due to induced apoptotic cell death via, p53, caspase-3 and c-myc-dependent pathways [28]. It has been reported that, chloroform extract exhibited anticancer activity in human ovarian Caov-3 carcinoma. Cytotoxicity of the extract was measured using the methylene blue assay [29].

\section{Identification of the compounds}

In this study, compounds showing anticancer activity have been isolated and partially purified from the methanolic leaf extract of Physalis minima. The isolated compounds were identified as flavonoids. Plants have been a prime source of highly effective conventional drugs for the treatment of many forms of cancer. Physalis minima has been reported to contain withanone, withaferin $A$, withanolide $A$, stigmasterol, sitosterol have been reported from leaves, root and stem while withanolide $A$, withanone, withaferin (fruits and flowers), dihydroxyphysalin B2-4 and physalins $A$. B and $X$. It also contain physalindicanols, withaphysalin $E$, withaphysalin $C$, withaphysalin $D$, withaphysalin $A$, physalinicanol $A$ withametelins, physalin, withanolide, withangulatins, vitasteroids, phygrine, withaphysalin $A, B, C, D, E$ and physalin $A, C$, $B, D, I, L$, withanone, withaferin $A$ and withanolide $A$. The plant contains seven withanolides like physalindicanols $A$ and $B$, withamin and withphysalin $E$ and other includes physalin $B, D, C$ and 3-0- glucosides of kaemferol and quercetin. Physalin $A, B, C$ and flavanoids, physalin $H$, isophysalin $B$, and $5 \beta, 6 \beta$-epoxyphysalin $B$. Two new physalins have been isolated from the whole plant of $P$. minima. It is also reported to contain withaminimin, phygrine (alkaloid), physalin L, a 13,14-seco16,24 cyclosteroid, other compound physalin B, epoxyphysalin B and physalin D, flavonoid, viz. 5-methoxy-6, 7methylenedioxyflavone and 5,6, 7-trimethoxyflavone and bitter principles[30]. 


\section{CONCLUSIONS}

In conclusion, the results obtained in the in vitro models such as SRB assay and MTT assay clearly suggests that, the methanolic leaf extract of Physalis minima showed strong cytotoxic activity. The results of the present work strongly suggest that phenolic compounds are important components of this plant and some of their pharmacological effects could be attributed to the presence of these valuable constituents. Thus, the anticancer activity of the extract could be predicted from its total phenolic content. The study showed that the extracts can be used as easily accessible source of natural anticancer agents and as a possible food supplement.

\section{Acknowledgements}

The financial assistance of University Grants Commission (UGC), Bengaluru is gratefully acknowledged. The authors are thankful to Prof. C.K. Renukarya, Director, Pooja Bhagavat Memorial Mahajana Education Centre, Post Graduate wing of SBRR Mahajana First Grade College, Metagalli, Mysuru for providing necessary facilities to carry out the research work.

\section{REFERENCES}

[1] Sugimura T, Toxicology, 2002, 181-182, 17-21.

[2] Eva JM, Angel GL, Laura P, Ignacio A, Antonia C, Federico GA, BMC Cancer 2006, 6(1), 119.

[3] Hartwell JL, Lawrence, Massachusetts, 1982, 709 pp.

[4] The Wealth of India, National Institute of Science Communication and Information Resources, New Delhi, 2003, pp, 307-308.

[5] Kirtikar KR, Basu BD. Indian Medicinal Plants, 2008, 3, pp, 1766-1767.

[6] Parmar C, Kaushal MK, Kalyani Publishers, New Delhi, 1982, pp, 62-65.

[7] Sinha SC, Ray AB, J Indian Chem Soc, 1988, 65, 740-741.

[8] Vipin P, Ashok A, Indian J Trad Knowledge, 2010, 9(3), 519-521.

[9] Vardhana R, Sarup and Sons, 2008, p,270.

[10 ]Zakaria M, Mohamad MA, ITNM, 2010, pp, 175-185.

[11] Raju VS, Reddy CS, Rajarao KG, Acta Phytotaxonomica Sinica, 2007, 45(2), 239-245.

[12] Anisuzzaman M, Rahman AHMM, Harun-Or-Rashid M, Naderuzzaman ATM, Islam AKMR, J Appl Sci Res, 2007, 3(7), 519-530.

[13] Khandelwal KR, Practical Pharmacognosy, 2004, pp, 149-156.

[14] Singleton VL, Rossi JA, American Chemical Society Symposium series, 1965, 26, 47-70.

[15] Zhishen J, Mengcheng T, Jianming W, Food Chem, 1999, 64, pp. 555-559.

[16] Phillips HJ, Terryberry JE, Cell Research, 1957, 13, 341-347.

[17] Masters RW, Animal cell culture, 2000, p, 1 - 3.

[18] Skehan P, Storeng R, Scudiero D, Monks A, McMahon J, Vistica D, Journal National Cancer Institute, 1990, 82(13), 1107-1112.

[19] Masters RW, Animal cell culture, 2000, p, 202-203.

[20] Mosmann T, Journal of Immunology Methods, 1983, 65, 55-63.

[21] Masters RW, Animal cell culture, 2000, p, 207.

[22] Jainu M, Devi CS, Journal of Ethnopharmacology, 2006, 104, 156-63.

[23] Shishodia S, Aggarwal BB, Oncogene, 2006, 25, 1463-73.

[24] Heinrich M, Bremner P, Curr Drug Targets, 2006, 7, 239.

[25] Larson RA, Phytochem, 1988, 27, 969- 978.

[26] Tanaka M, Kuei CW, Nagashima Y, Taguchi T, Nippon Suisan Gakkaishi, 1998, 54, 1409- 1414.

[27] Leong OK, Tengku Muhammad TS, Sulaiman SF, Evid-Based Complent Altern Med eCAM, 2009, p, 1-10.

[28] Leong OK, Tengku Muhammad TS, Integr Cancer Ther, 2010, 9(1), 73-83.

[29] Leong OK, Tengku Muhammad TS, Sulaiman SF, J Ethnopharmacol, 2010, 28(1-2), 92-99.

[30] Daya L Chothani, Vaghasiya HU, Indian Journal of Natural Products and Resources, 2012, 3(4), 477-482. 